\title{
Characterization and Pathogenicity of Botryosphaeriaceae Species Obtained from Avocado Trees with Branch Canker and Dieback and from Avocado Fruit with Stem End Rot in Chile
}

\author{
Ana L. Valencia, ${ }^{\dagger}$ Pilar M. Gil, Bernardo A. Latorre, and I. Marlene Rosales \\ Facultad de Agronomía e Ingeniería Forestal, Pontificia Universidad Católica de Chile, Macul, Santiago, Chile
}

\begin{abstract}
Several species of the Botryosphaeriaceae family have been associated with branch canker, dieback, and stem end rot in avocado (Persea americana Mill.). In Chile, the incidence of diseases affecting the avocado tree increased from 2011 to 2016, which coincided with a severe drought that affected avocado production. Moreover, distant countries importing avocados from Chile also reported an increase of stem end rot of ripe avocados. Therefore, the aims of this study were to identify the pathogen species associated with branch canker, dieback, and stem end rot of avocado in Chile and to study their pathogenicity. This study was conducted between 2015 and 2016 in 'Hass' avocado orchards located in the main avocado-producing regions in Chile. A diverse collection of fungal species was recovered from both necrotic woody tissue and necrotic tissue on harvested ripe fruit. On the basis of morphology and phylogenetic analyses of the internal transcribed spacer region (ITS15.8S-ITS2) and the translation elongation factor $1-\alpha$ (TEF1- $\alpha$ ) gene,

eight species in the Botryosphaeriaceae family were identified: Diplodia mutila, D. pseudoseriata, D. seriata, Dothiorella iberica, Lasiodiplodia theobromae, Neofusicoccum australe, $N$. nonquaesitum, and $N$. parvum. For each of these species, pathogenicity studies were conducted on 1-year-old healthy Hass avocado plants. All isolates produced brown gum exudate and caused necrosis in the vascular system 3 weeks after inoculation. $N$. nonquaesitum, $N$. parvum, and D. pseudoseriata were the most virulent species. Necrotic lesions and cavities with white mycelia near the peduncle union were observed on Hass avocado fruit inoculated postharvest. L. theobromae, N. australe, and $N$. parvum were significantly more virulent than the other tested species in the Botryosphaeriaceae family. This study identified and characterized the pathogenicity of Botryosphaeriaceae species in Chile, which will prove useful to future research on these pathogens directed at establishing effective control strategies in avocado.
\end{abstract}

The family Botryosphaeriaceae encompass a morphologically diverse family of Ascomycota fungi (Phillips et al. 2013). Some species can survive as endophytes in symptomless tissue (Twizeyimana et al. 2013) and become pathogenic when the host is subjected to stress conditions (Dann et al. 2013; Slippers and Wingfield 2007). Species in the Botryosphaeriaceae family are associated with a wide variety of woody hosts (Slippers and Wingfield 2007). On Persea americana Mill., the species of Botryosphaeriaceae have been associated with branch canker and dieback in avocado trees in different countries. In this sense, Menge and Ploetz (2003) have indicated that Botryosphaeria dothidea (Moug. ex Fr.) Ces. \& De Not is the most common pathogen reported in Chile, Mexico, New Zealand, Peru, South Africa, and the United States. In addition, B. obtusa (Schwein.) Shoemaker and B. rhodina (Berk. \& M.A. Curtis) Arx have been reported in Mexico and the United States. Other species previously reported are Diplodia mutila (Fr.) Mont. in the United States (Chen et al. 2014); Dothiorella iberica A.J.L. Phillips, J. Luque \& A. Alves in the United States (McDonald and Eskalen 2011); Lasiodiplodia theobromae (Pat.) Griffon \& Maubl in Tanzania (Alves et al. 2008); Neofusicoccum australe (Slippers, Crous \& M.J. Wingf.) Crous, Slippers \& A.J.L. Phillips in Chile (Auger et al. 2013) and the United States (McDonald et al. 2009); N. luteum (Pennycook \& Samuels) Crous, Slippers \& A.J.L. Phillips in the United States (McDonald et al. 2009); N. nonquaesitum Inderb., Trouillas, Bostock \& Michailides in the United States

${ }^{\dagger}$ Corresponding author: A. L. Valencia; E-mail: alvalenc@puc.cl

Funding: Financial support was received from the Doctoral Scholarship CONICYT-PCHA 21140282, Project CONICYT-PAI 781413002, Subsole S.A., and Dirección de Investigación y Postgrados of Facultad de Agronomía e Ingeniería Forestal.

Accepted for publication 9 November 2018.

@ 2019 The American Phytopathological Society
(Carrillo et al. 2016); and N. parvum (Pennycook \& Samuels) Crous, Slippers \& A.J.L. Phillips in Italy (Guarnaccia et al. 2016), Spain (Zea-Bonilla et al. 2007), and the United States (McDonald et al. 2009).

On avocado, branch cankers are typified by necrotic, friable bark, often with whitish hard exudates of perseitol, a crystalline polyhydric alcohol produced by avocados. Internally, the wood becomes reddish brown (Auger et al. 2013; Dann et al. 2013; McDonald and Eskalen 2011; Menge and Ploetz 2003). Infection under the bark makes it possible for the fungus to colonize the vascular tissue and affect water and nutrient transport throughout the xylem and the translocation of assimilates through the phloem tissue (Eskalen et al. 2013). This blockage causes weakening and decay of the woody tissue, which can eventually lead to branch wilt and dieback (Auger et al. 2013; McDonald and Eskalen 2011). This condition can also affect the accumulation and availability of the reserves necessary for fruiting during the following season, which are primarily located in the trunk and branches (Chanderbali et al. 2013). Thus, branch canker and dieback can reduce the productivity of the orchard.

Latent fruit infections of Botryosphaeriaceae species can also occur in orchards affected by branch canker and dieback (Hopkirk et al. 1994; Menge and Ploetz 2003). This infection can remain dormant until the environment is favorable for the pathogen (Aly et al. 2011). Rotting is rarely observed on immature avocado fruit before harvesting, because fruit will ripen only when it is removed from the tree, causing increases in the rate of respiration and ethylene production (Yahia and Woolf 2011). Moreover, as the fruit ripens, there is a decrease in the concentrations of the antifungal diene, a preformed antifungal component of avocado (Hopkirk et al. 1994; Prusky and Keen 1993), which increases the fruit susceptibility to infection.

Avocado stem end rot starts at the scar left after the removal of the stem during harvest (Dann et al. 2013; Menge and Ploetz 2003). The initial symptom may be a slight softening at the union where the stem attaches to the fruit that continues with the discoloration of the pulp. These symptoms are followed by the development of mycelia and conidia in the abscission zone (Dann et al. 2013; Johnson and Kotzé 
1994). These lesions grow rapidly as the fruit matures, completely compromising the fruit (White et al. 2005). The pathogens associated with stem end rot include species of the Botryosphaeriaceae family and other fungal species, such as Colletotrichum gloeosporioides (Penz.) Penz. \& Sacc, C. acutatum J.H. Simmonds, Thyronectria pseudotrichia (Schwein.) Seeler, Phomopsis perseae Zerova, Pestalotiopsis clavispora (G.F. Atk.) Steyaert, and P. versicolor (Speg.) Steyaert (Dann et al. 2013; Darvas and Kotzé 1987; Hartill and Everett 2002; Menge and Ploetz 2003; Valencia et al. 2011). However, anamorphs of species in the Botryosphaeriaceae have been considered to be the important causal agents of avocado stem end rot throughout the world (Dann et al. 2013; Menge and Ploetz 2003), including D. mutila in the United States (Inderbitzin et al. 2010), L. theobromae in Italy (Dann et al. 2013; Garibaldi et al. 2012), N. australe in Chile (Montealegre et al. 2016) and Turkey (Akgül et al. 2016), N. luteum in the United States (Twizeyimana et al. 2013), N. mangiferae (Syd. \& P. Syd.) Crous, Slippers \& A.J.L. Phillips in Taiwan (Ni et al. 2009), N. mediterraneum Crous, M.J. Wingf. \& A.J.L. Phillips in the United States (Inderbitzin et al. 2010), and N. parvum in Italy (Guarnaccia et al. 2016) and Mexico (Molina-Gayosso et al. 2012).

Chile is considered one of the largest avocado-producing countries in the world, with 30,078 ha planted between the Atacama Region $\left(25^{\circ} 17^{\prime} \mathrm{S}\right.$ to $\left.29^{\circ} 30^{\prime} \mathrm{S}\right)$ and the O'Higgins Region $\left(33^{\circ} 51^{\prime} \mathrm{S}\right.$ to $35^{\circ} 01^{\prime}$ $\mathrm{S})$, with the Valparaiso region $\left(32^{\circ} 02^{\prime} \mathrm{S}\right.$ to $\left.33^{\circ} 57^{\prime} \mathrm{S}\right)$ being the most productive (ODEPA-CIREN 2017). In Chile, the avocados are produced in high-density planting, which requires frequent pruning (Schaffer et al. 2013), thus increasing the infection risk through pruning wounds (Dann et al. 2013; Eskalen et al. 2013).

The primary avocado fruit cultivar exported from Chile is 'Hass', which is sent by overseas transport to distant markets in the United States, Europe, and Asia. Therefore, it is essential to produce fruit with a long postharvest shelf life that can withstand prolonged storage. However, since 2014, the incidence of stem end rot has increased in import markets that consume Chilean fruit. The quality of sanitation is important to guarantee the distribution and sale of the Chilean avocados in these markets, such as the Asian market, but especially in the European markets, where maturation chambers are used for reducing the ripening times of the fruit, by increasing temperature, ethylene concentration, and relative humidity in storage, which allows avocados to be sold ready-to-eat.

In Chile, there is not sufficient information about all the pathogens associated with branch canker, dieback, and stem end rot. This critical information is needed to develop cultural strategies for disease management. Therefore, the aims of this study were to identify the pathogen species associated with branch canker, dieback, and stem end rot of avocado in Chile and to study their pathogenicity.

\section{Materials and Methods}

Field sampling. Sampling was conducted in 16 Hass avocado orchards located between Illapel ( $\left.31^{\circ} 37^{\prime} \mathrm{S}\right)$ and Peumo $\left(34^{\circ} 24^{\prime} \mathrm{S}\right)$ in the spring of 2015 and 2016. In each orchard, 15 symptomatic or healthy trees were randomly selected from an area of approximately $900 \mathrm{~m}^{2}$. A total of 75 wood samples of branch and/or discs cut from trunks were obtained per orchard (five wood samples from each tree) and transported to the laboratory, where they were immediately processed. A total of 45 fruits per orchard (three fruits per tree with peduncle attached) were harvested and transported to the laboratory in plastic bags. The fruits were surface disinfected by immersion in $75 \%$ ethanol for $30 \mathrm{~s}$ and then placed in humidity chambers $(100 \%$ relative humidity) for 7 to 31 days at $20^{\circ} \mathrm{C}$ until they reached the firmness of consumer maturity. Additionally, 15 fruits were harvested by the orchard and were sent to the laboratory to determine dry matter content, because avocados are harvested at about $23 \%$ dry matter in Chilean production.

Fungal isolation. The wood samples were disinfected by immersion in $96 \%$ ethanol for $15 \mathrm{~s}$ and immediately flamed for $15 \mathrm{~s}$, and the outer burned tissues were removed aseptically. Small wood pieces and pulp pieces of mature Hass fruit ( 3 to $5 \mathrm{~mm}$ ) were removed from the margins between the healthy and symptomatic tissues and placed in Petri dishes containing $2 \%$ potato dextrose agar acidified with
$0.5 \mathrm{ml} /$ liter of $92 \%$ lactic acid plus $0.05 \%$ tetracycline (Díaz et al. 2013). The plates were incubated at $20^{\circ} \mathrm{C}$ in darkness for 14 to 21 days. The colony features were used to tentatively identify morphologically isolates of Botryosphaeriaceae species, because only some isolates generated conidiophores and conidia at this stage. Therefore, conidial features were later used to identify these isolates to species level. All isolates with these features were transferred to acidified potato dextrose agar (APDA). Pure cultures were obtained from hyphal tip transfers. All the isolates were stored in $1.5 \mathrm{ml}$ of sterile $20 \%$ glycerol at $5^{\circ} \mathrm{C}$.

Morphological characterization. Colony morphology was characterized on APDA after 5, 12, and 27 days at $25^{\circ} \mathrm{C}$ in darkness. Conidiophores and conidia were produced by placing small pieces of mycelia on $2 \%$ water agar amended with autoclaved pine needles and incubated for 21 days at $15^{\circ} \mathrm{C}$ in darkness or from 30-day-old colonies cultivated on APDA at $20^{\circ} \mathrm{C}$ in darkness. The length and width of 50 conidia were measured, and the mean and standard deviation were calculated. The color, shape, and presence or absence of septation of conidia were also determined. The descriptions of Phillips et al. (2013) were used to identify the isolates obtained.

Based on the morphological characteristics, 11 isolates obtained from wood and 17 isolates obtained from fruits were selected for further characterization of their growth rates at various temperatures, gene sequence analysis, and pathogenicity testing.

Temperature effects on mycelial growth. Mycelial discs (5 mm in diameter) of 28 selected isolates were transferred to APDA in Petri dishes and incubated for 4 days, at $5,10,15,20,25,30,35$, and $40^{\circ} \mathrm{C}$ in darkness. For each isolate, three replicate plates were incubated, and the experiment was conducted twice. The colony diameter was measured daily, and the average growth rate was determined on the second and third days at each temperature, prior to the mycelia reaching the edges of the plates.

DNA extraction, polymerase chain reaction (PCR) amplification, and sequencing. Mycelial plugs from each isolate $(n=28)$ were obtained from 4-day-old colonies cultivated on APDA at $20^{\circ} \mathrm{C}$ and placed into 2-ml tubes with glass and metal beads. The tubes were placed into a Mini-Beadbeater-24 (Bio Spec Products, Bartlesville, $\mathrm{OK}$ ) for $30 \mathrm{~s}$ at 3,500 strokes/min. The DNA was obtained using a Wizard Genomic DNA purification kit (Promega Corporation, Madison, WI). The ITS1-5.8S-ITS2 region of the ribosomal DNA was amplified using primers ITS1 and ITS4 (White et al. 1990), and the amplification of the partial sequence of the translation elongation factor 1- $\alpha$ (TEF1- $\alpha)$ was conducted using primers TEF1-728F and TEF1-986R (Carbone and Kohn 1999). PCR was performed with a $50-\mu 1$ reaction mixture containing $5 \times$ PCR reaction buffer, $25 \mathrm{mM}$ $\mathrm{MgCl}_{2}, 10 \mathrm{mM}$ dNTPs, $10 \mu \mathrm{M}$ of each primer, $1 \mathrm{U}$ of GoTaq G2 Flexi DNA polymerase (Promega Corporation), and 50 to $100 \mathrm{ng} / \mu \mathrm{l}$ of DNA. Negative controls with sterile water, a positive control of an isolate of $N$. parvum obtained in a previous study, and DNA samples of 28 selected isolates were used in each PCR reaction. The PCR conditions using the primers ITS 1 and ITS4 were 5 min of initial denaturation at $95^{\circ} \mathrm{C}$, followed by 35 cycles of $30 \mathrm{~s}$ of denaturation at $95^{\circ} \mathrm{C}, 30 \mathrm{~s}$ of alignments at $55^{\circ} \mathrm{C}, 45 \mathrm{~s}$ of extension at $72^{\circ} \mathrm{C}$, and a final extension of $7 \mathrm{~min}$ at $72^{\circ} \mathrm{C}$. For the primers TEF1-728 and TEF1-986, the PCR conditions were 5 min of initial denaturation at $95^{\circ} \mathrm{C}$, followed by 30 cycles of $20 \mathrm{~s}$ of denaturation at $95^{\circ} \mathrm{C}, 20 \mathrm{~s}$ of alignments at $55^{\circ} \mathrm{C}, 45 \mathrm{~s}$ of extension at $72{ }^{\circ} \mathrm{C}$, and a final extension of $7 \mathrm{~min}$ at $72^{\circ} \mathrm{C}$. Next, $5 \mu \mathrm{l}$ of PCR product of each PCR reaction was examined by electrophoresis at $100 \mathrm{~V}$ on a $1.5 \%$ agarose gel $(\mathrm{w} / \mathrm{v})$ in $1 \times$ TAE buffer and visualized with ultraviolet light. A 100-bp DNA ladder (Maestrogen, Prion Lab, Santiago, Chile) was used as the size marker. The PCR product was purified and sequenced by Macrogen (Seoul, South Korea), and the sequences obtained were edited using Proseq version 2.91 (Filatov 2002) and were aligned using Clustal $X$ version 2.0 (Larkin et al. 2007). The sequences of Botryosphaeriaceae species obtained in this study (Table 1) were compared using BLASTn analysis with sequences existing in the GenBank database (Table 2).

Phylogenetic analyses. The phylogenetic analysis was performed using Mega 6 (Tamura et al. 2013) with the ITS and TEF1- $\alpha$ datasets 
separate and combined, including sequences of Melanops tulasnei as an outgroup (Table 2). The combined sequences of the ITS and TEF1- $\alpha$ regions were aligned using Clustal W (Larkin et al. 2007), and uninformative terminal regions were excluded from the analysis. The partition homogeneity test was conducted using PAUP 4.0 (Swofford 2002) to determine the statistical congruence between the ITS and TEF1- $\alpha$ datasets and to determine if they could be combined in a single dataset $(P=0.05)$.

The maximum parsimony analysis was performed using a heuristic search option and the tree bisection reconnection algorithm with 1,000 bootstrap replications and complete deletion of gaps and missing data. In addition, tree length, consistency index (CI), retention index $(\mathrm{RI})$, and rescaled consistency index (RCI) were registered.

Table 1. Species, location, and GenBank accession numbers of Botryosphaeriaceae isolates obtained from avocado trees with branch canker and dieback and from avocado fruits with stem end rot in Chile

\begin{tabular}{|c|c|c|c|c|}
\hline \multirow[b]{2}{*}{ Species } & \multirow[b]{2}{*}{ Isolate $^{y}$} & \multirow{2}{*}{$\begin{array}{l}\text { Location } \\
\text { (latitude) }\end{array}$} & \multicolumn{2}{|c|}{$\begin{array}{c}\text { GenBank accession } \\
\text { numbers }^{\mathrm{z}}\end{array}$} \\
\hline & & & ITS & TEF1- $\alpha$ \\
\hline Diplodia mutila & PALUC1M & Ocoa $\left(32^{\circ} 5^{\prime} \mathrm{S}\right)$ & MF568683 & MF581780 \\
\hline D. mutila & PALUC18M & Ocoa $\left(32^{\circ} 50^{\prime} \mathrm{S}\right)$ & MF578221 & MF687922 \\
\hline D. mutila & PALUC45F & Ocoa $\left(32^{\circ} 50^{\prime} \mathrm{S}\right)$ & MF578747 & MF687932 \\
\hline D. mutila & PALUC451F & $\begin{array}{l}\text { Melipilla } \\
\quad\left(33^{\circ} 46^{\prime} \mathrm{S}\right)\end{array}$ & MF578748 & MF687933 \\
\hline D. pseudoseriata & PALUC406M & $\begin{array}{l}\text { Quillota } \\
\left(32^{\circ} 53^{\prime} \mathrm{S}\right)\end{array}$ & MF578222 & MF687923 \\
\hline D. seriata & PALUC14M & $\begin{array}{l}\text { San Felipe } \\
\left(32^{\circ} 44^{\prime} \mathrm{S}\right)\end{array}$ & MF578223 & MF687924 \\
\hline D. seriata & PALUC404M & $\begin{array}{l}\text { Jaururo } \\
\left(32^{\circ} 28^{\prime} \mathrm{S}\right)\end{array}$ & MF578224 & MF687925 \\
\hline D. seriata & PALUC10F & Ocoa $\left(32^{\circ} 50^{\prime} \mathrm{S}\right)$ & MF578749 & MF687934 \\
\hline D. seriata & PALUC426F & $\begin{array}{l}\text { Jaururo } \\
\left(32^{\circ} 28^{\prime} \mathrm{S}\right)\end{array}$ & MF578750 & MF687935 \\
\hline D. seriata & PALUC455F & $\begin{array}{l}\text { Melipilla } \\
\left(33^{\circ} 46^{\prime} S\right)\end{array}$ & MF578751 & MF687936 \\
\hline D. seriata & PALUC467F & $\begin{array}{l}\text { Peumo } \\
\quad\left(34^{\circ} 23^{\prime} S\right)\end{array}$ & MF578752 & MF687937 \\
\hline $\begin{array}{l}\text { Dothiorella } \\
\text { iberica }\end{array}$ & PALUC3M & $\begin{array}{l}\text { San Felipe } \\
\left(32^{\circ} 44^{\prime} \mathrm{S}\right)\end{array}$ & MF578225 & MF687926 \\
\hline D. iberica & PALUC399M & $\begin{array}{l}\text { Alicahue } \\
\left(32^{\circ} 24^{\prime} \mathrm{S}\right)\end{array}$ & MF578226 & MF687927 \\
\hline D. iberica & PALUC7F & $\begin{array}{l}\text { San Felipe } \\
\left(32^{\circ} 44^{\prime} \mathrm{S}\right)\end{array}$ & MF578753 & MF687938 \\
\hline $\begin{array}{c}\text { Lasiodiplodia } \\
\text { theobromae }\end{array}$ & PALUC449F & $\begin{array}{l}\text { Alicahue } \\
\left(32^{\circ} 24^{\prime} \mathrm{S}\right)\end{array}$ & MF578754 & MF687939 \\
\hline $\begin{array}{l}\text { Neofusicoccum } \\
\text { australe }\end{array}$ & PALUC439F & $\begin{array}{l}\text { Jaururo } \\
\quad\left(32^{\circ} 28^{\prime} \mathrm{S}\right)\end{array}$ & MF578755 & MF687940 \\
\hline N. australe & PALUC454F & $\begin{array}{l}\text { Melipilla } \\
\left(33^{\circ} 46^{\prime} \mathrm{S}\right)\end{array}$ & MF578756 & MF687941 \\
\hline N. australe & PALUC474F & $\begin{array}{l}\text { Peumo } \\
\quad\left(34^{\circ} 23^{\prime} \mathrm{S}\right)\end{array}$ & MF578757 & MF687942 \\
\hline N. australe & PALUC490F & $\begin{array}{l}\text { Melipilla } \\
\left(33^{\circ} 45^{\prime} \mathrm{S}\right)\end{array}$ & MF578758 & MF687943 \\
\hline N. nonquaesitum & PALUC4M & Ocoa $\left(32^{\circ} 50^{\prime} \mathrm{S}\right)$ & MF578228 & MF687929 \\
\hline N. nonquaesitum & PALUC407M & $\begin{array}{l}\text { Quillota } \\
\qquad\left(32^{\circ} 53^{\prime} \mathrm{S}\right)\end{array}$ & MF578227 & MF687928 \\
\hline N. parvum & PALUC16M & Ocoa $\left(32^{\circ} 50^{\prime} \mathrm{S}\right)$ & MF578229 & MF687930 \\
\hline N. parvum & PALUC411M & $\begin{array}{l}\text { Peumo } \\
\quad\left(34^{\circ} 23^{\prime} \mathrm{S}\right)\end{array}$ & MF578230 & MF687931 \\
\hline N. parvum & PALUC6F & Ocoa $\left(32^{\circ} 50^{\prime} \mathrm{S}\right)$ & MF578759 & MF687944 \\
\hline N. parvum & PALUC44F & Ocoa $\left(32^{\circ} 50^{\prime} \mathrm{S}\right)$ & MF578760 & MF687945 \\
\hline N. parvum & PALUC415F & $\begin{array}{l}\text { Quillota } \\
\qquad\left(32^{\circ} 53^{\prime} \mathrm{S}\right)\end{array}$ & MF578761 & MF687946 \\
\hline N. parvum & PALUC470F & $\begin{array}{l}\text { Peumo } \\
\quad\left(34^{\circ} 23^{\prime} \mathrm{S}\right)\end{array}$ & MF578762 & MF687947 \\
\hline N. part & PALUC496F & $\begin{array}{l}\text { Melipilla } \\
\left(33^{\circ} 45^{\prime} S\right)\end{array}$ & MF578763 & MF687948 \\
\hline
\end{tabular}

${ }^{y}$ Source: $\mathrm{M}=$ avocado wood, and $\mathrm{F}=$ avocado fruit.

${ }^{\mathrm{z}}$ ITS $=$ internal transcribed spacer, and TEF $1-\alpha=$ translation elongation factor $1-\alpha$.
Pathogenicity testing. Pathogenicity tests were conducted on Hass avocado plants and fruits.

Pathogenicity testing on young trees. One-year-old Hass avocado trees grafted onto Mexicola rootstock were kept in the shade for 60 days with optimal nutrition and irrigation. All plants $(n=36)$ were wounded with a scalpel before inoculation with a 7-day-old mycelial plug (5 mm in diameter) of D. mutila (PALUC1M, PALUC18M), D. pseudoseriata (PALUC406M), D. seriata (PALUC14M, PALUC404M), D. iberica (PALUC3M, PALUC399M), N. nonquaesitum (PALUC4M, PALUC407M), and N. parvum (PALUC16M, PALUC411M). Control plants were treated with sterile agar discs ( $5 \mathrm{~mm}$ in diameter). The wounded zone in the stem was sealed with Parafilm to avoid dehydration. The experimental design was completely randomized with three replicates for each treatment. The length of the necrotic inner lesion that developed in the stem was measured. These data were subjected to statistical analysis using a one-way analysis of variance (ANOVA), and the means were separated by Tukey's honestly significant difference (HSD) test $(P=$ 0.05), using SAS version 9 (SAS Institute, Cary, NC). Koch's postulates were confirmed after the reisolation from pieces of damaged stem placed on APDA at $20^{\circ} \mathrm{C}$ for 7 days. The experiment was repeated once.

Pathogenicity testing on harvested fruit. Pathogenicity testing of Botryosphaeriaceae isolates was conducted on Hass avocado fruit that were harvested at maturity $(25.6 \%$ mean dry matter). The fruits $(n=54)$ were surface disinfected by immersion for $30 \mathrm{~s}$ in $75 \%$ ethanol and wounded in the peduncle cavities before inoculation with 7-day-old mycelial discs (5 $\mathrm{mm}$ in diameter) of D. mutila (PALUC45F, PALUC451F), D. seriata (PALUC10F, PALUC426F, PALUC455F, PALUC467F), D. iberica (PALUC7F), L. theobromae (PALUC449F), N. australe (PALUC439F, PALUC454F, PALUC474F, PALUC490F), and N. parvum (PALUC6F, PALUC44F, PALUC415F, PALUC470F, PALUC496F). Control fruits were treated with sterile agar discs $5 \mathrm{~mm}$ in diameter. The wounded zone in the fruit was sealed with Parafilm to avoid dehydration. The fruits were placed in humidity chambers $\left(100 \%\right.$ relative humidity) at $20^{\circ} \mathrm{C}$ for 10 days. The experimental design was a completely randomized design with three replicates of each treatment. The length of the necrotic inner lesions that developed in fruits was measured, and these data were subjected to statistical analysis using a one-way ANOVA, and the means were separated by Tukey's HSD test $(P=0.05)$ using SAS version 9 (SAS Institute).

Pathogenicity testing on stored fruit. The Hass avocado fruits were surface disinfected and wounded as described above. Later, the fruits were inoculated with 7-day-old mycelial discs (5 $\mathrm{mm}$ in diameter) of D. mutila (PALUC45F, PALUC451F), D. seriata (PALUC426F, PALUC455F), D. iberica (PALUC7F), L. theobromae (PALUC449F), N. australe (PALUC439F, PALUC490F), and N. parvum (PALUC6F, PALUC415F, PALUC470F, PALUC496F). Control fruits were treated with sterile agar discs (5 mm in diameter). All fruits $(n=65)$ were stored in cardboard boxes, sealed with plastic film to avoid contamination. These fruits were maintained for 15 , 30 , or 45 days at cold storage of $5^{\circ} \mathrm{C}$ plus 7 days at $20^{\circ} \mathrm{C}$ in a normal atmosphere (without changes in atmosphere composition of $\mathrm{CO}_{2}$ and $\mathrm{O}_{2}$ ). The treatments were distributed as a completely randomized design with five replicates per treatment. The length of the necrotic inner lesion in fruits was measured, and these data were subjected to statistical analysis using an ANOVA with treatments arranged factorially with 13 isolates at three storage times. The means were separated by Tukey's HSD test $(P=0.05)$ using SAS version 9 (SAS Institute). To fulfill Koch's postulates, pieces of fruit obtained from margins of symptomatic tissue of both tests were placed on APDA at $20^{\circ} \mathrm{C}$ for 7 days. The isolates were reidentified based on their cultural and morphological features.

\section{Results}

Field sampling. Of the 16 orchards, six orchards had symptoms associated with branch canker and dieback on both young plants used for replanting and adult trees. Symptoms included branches with wilting leaves and inflorescences, and small fruits with abnormal 
development. In addition, harvested fruit from 11 of the 16 orchards showed stem end rot on ripe fruit. On severely affected fruit, white to gray mycelia appeared on the peel near the peduncle, and occasionally black pycnidia with masses of gray conidia completely covered the fruit. The inner tissue also had cavities with white mycelia and necrosis deep in the pulp. In less affected fruit, mycelia and conidia were absent in the peel, but after removal of the peduncle a slight necrosis of the pulp internally extending until the equatorial zone was observed.

Fungal isolation. Thirty-six and 88 isolates obtained from the samples of wood and fruit, respectively, showed characteristics of species belonging to Botryosphaeriaceae. These isolates originated from orchards in different geographical locations with different climatic conditions (Table 1).

Morphological characterization. Isolates obtained were grouped into seven groups based on their colony and conidial features.

Group 1, D. mutila. The colony grew primarily flattened (nearly absent of dense aerial mycelia) and was initially white, turning olive gray to black. The pycnidia were usually aggregated, black, semiglobose, and partially erumpent on pine needles. The conidia were initially hyaline, aseptate, smooth, oblong to ovoid, with both ends rounded, and with age, pale brown with one septum, reaching sizes of 20.6 to $30.3 \times 9.4$ to $17.9 \mu \mathrm{m}$ (Table 3 ). Ascomata were not observed. These isolates were morphologically similar to the description of $D$. mutila (Alves et al. 2004).

Group 2, D. seriata. The colony grew primarily flattened, initially white and later turned gray to black. The pycnidia usually were aggregated, black, erumpent, and partially emergent on pine needles. The conidia were initially light brown, aseptate, smooth, oblong, with their base truncate or rounded and dark brown with age, of 17.6 to $32.3 \times 7.7$ to $14.2 \mu \mathrm{m}$ (Table 3 ). Ascomata were not observed. These isolates were morphologically similar to the description of D. seriata (Phillips et al. 2013) and D. pseudoseriata (Pérez et al. 2010).
Group 3, D. iberica. The colony grew primarily flattened, initially white with gray centers and turned from brown to dark gray or black. The pycnidia were usually thick walled, solitary, black, and globose. The conidia were dark brown with one septum, smooth, and obovoid with a rounded apex and truncate base, and some conidia were slightly constricted at the septum of 22.7 to $28.8 \times 8.5$ to $13.7 \mu \mathrm{m}$ (Table 3). Ascomata were not observed. These isolates were morphologically similar to the description of D. iberica (Phillips et al. 2005).

Group 4, L. theobromae. The colony developed abundant filamentous mycelia, which initially were white with a gray center and turned gray to dark gray or black. The pycnidia were usually simple or aggregated and black in color. The paraphyses were present as hyaline, cylindrical, and hyphal-like with rounded ends, $51.8 \mu \mathrm{m}$ long and $3.47 \mu \mathrm{m}$ wide on average. The conidia were hyaline, with granular contents, thick walled, subovoid to ellipsoid-ovoid, dark brown with one septum, developing longitudinal striation with age, of 16.7 to $26.2 \times 11.1$ to $14.5 \mu \mathrm{m}$ (Table 3). Ascomata were not observed. These isolates were morphologically similar to the description of L. theobromae (Phillips et al. 2013).

Group 5, N. australe. The colony developed dense filamentous mycelia with tufts of aerial mycelia around the edges, which initially were white and turned to light gray to dark gray or black. The pycnidia were usually solitary, black, and globose. The conidia were hyaline, aseptate, with granular content, fusiform-obovoid, with a truncate to lightly rounded base, of 17.7 to $29.9 \times 6.2$ to $13.6 \mu \mathrm{m}$ (Table 3). Ascomata were not observed. These isolates were morphologically similar to the description of $N$. australe (Phillips et al. 2013).

Group 6, N. nonquaesitum. The colony developed dense filamentous mycelia, which initially were white and turned to light gray to dark gray to black. The pycnidia were usually simple or aggregate, black, and, in some cases, had a short neck. The conidia were hyaline, aseptate, with granular content, and fusiform, of 18.7 to $31.7 \times 4.9$ to $9.4 \mu \mathrm{m}$ (Table 3). Ascomata were not observed. These isolates were

Table 2. Sequences of Botryosphaeriaceae species obtained from GenBank that were included in the phylogenetic analysis

\begin{tabular}{|c|c|c|c|c|c|c|}
\hline \multirow[b]{2}{*}{ Species } & \multirow[b]{2}{*}{ Isolate $^{y}$} & \multirow[b]{2}{*}{ Host } & \multirow[b]{2}{*}{ Origin } & \multirow[b]{2}{*}{ Reference } & \multicolumn{2}{|c|}{$\begin{array}{c}\text { GenBank accession } \\
\text { number }^{\mathbf{z}}\end{array}$} \\
\hline & & & & & ITS & TEF1- $\alpha$ \\
\hline Botryosphaeria dothidea & CMW8000 & Prunus sp. & Switzerland & Slippers et al. (2004a) & AY236949 & AY236898 \\
\hline Diplodia mutila & CBS 112553 & Vitis vinifera & Portugal & Alves et al. (2004) & AY259093 & AY573219 \\
\hline D. mutila & PD61 & Persea americana & U.S.A. & Inderbitzin et al. (2010) & GU251117 & GU251249 \\
\hline D. mutila & $4 \mathrm{D} 33$ & Persea americana & U.S.A. & Chen et al. (2014) & KF778789 & KF778979 \\
\hline D. pseudoseriata & CBS 124906 & Blepharocalyx salicifolius & Uruguay & Perez et al. (2010) & EU080927 & EU863181 \\
\hline D. seriata & CBS 112555 & Vitis vinifera & Portugal & Alves et al. (2004) & AY259094 & AY573220 \\
\hline D. seriata & Mz-F1 & Malus domestica & Chile & Unpublished & KU942427 & KU951888 \\
\hline D. seriata & $2 \mathrm{~K} 33$ & Punica granatum & U.S.A. & Chen et al. (2014) & KF778795 & KF778985 \\
\hline D. seriata & STE-U 5830 & Prunus sp. & South Africa & Damm et al. (2007) & EF445297 & EF445364 \\
\hline Dothiorella iberica & CBS 115041 & Quercus ilex & Spain & Phillips et al. (2005) & AY573202 & AY573222 \\
\hline D. sarmentorum & IMI 63581b & Ulmus sp. & England & Phillips et al. (2005) & AY573212 & AY573235 \\
\hline D. sarmentorum & CBS 115038 & Malus pumila & Netherlands & Phillips et al. (2005) & AY573206 & AY573223 \\
\hline D. sarmentorum & CBS 165.33 & Prunus armeniaca & Unknown & Phillips et al. (2005) & AY573208 & AY573225 \\
\hline Lasiodiplodia theobromae & CBS 164.96 & Fruit on coral reef & Papua New Guinea & Phillips et al. (2005) & AY640255 & AY640258 \\
\hline L. theobromae & CMW25212 & Mangifera indica & South Africa & Mehl et al. (2017b) & KU997392 & KU997128 \\
\hline L. theobromae & CAA006 & Vitis vinifera & U.S.A. & Alves et al. (2006) & DQ458891 & DQ458876 \\
\hline Neofusicoccum arbuti & CBS 116131 & Arbutus menziesii & U.S.A. & Phillips et al. (2013) & AY819720 & KF531792 \\
\hline N. australe & CMW 6837 & Acacia sp. & Australia & Slippers et al. (2004b) & AY339262 & AY339270 \\
\hline N. mediterraneum & PD312 & Eucalyptus sp. & Greece & Inderbitzin et al. (2010) & GU251176 & GU251308 \\
\hline N. mediterraneum & PD67 & Persea americana & U.S.A. & Inderbitzin et al. (2010) & GU251191 & GU251323 \\
\hline N. nonquaesitum & PD484 & Laurus nobilis & U.S.A. & Inderbitzin et al. (2010) & GU251163 & GU251295 \\
\hline N. nonquaesitum & UCR2733 & Persea americana & U.S.A. & Carrillo et al. (2016) & KT965281 & КT965283 \\
\hline N. parvum & ATCC 58191 & Populus nigra & New Zealand & Slippers et al. (2004a) & AY236943 & AY236888 \\
\hline Melanops tulasnei & CBS 116805 & Quercus robur & Germany & Phillips and Alves (2009) & FJ824769 & FJ824774 \\
\hline Melanops tulasnei & CBS 116806 & Quercus robur & Germany & Phillips and Alves (2009) & FJ824770 & FJ824775 \\
\hline
\end{tabular}

${ }^{y}$ Acronyms of culture collection: ATCC $=$ American Type Culture Collection, Virginia, U.S.A.; CAA = personal culture collection A. Alves, University of Aveiro, Portugal; CBS = Centraalbureau voor Schimmelcultures, Utrecht, the Netherlands; CMW = Tree Pathology Co-operative Program, Forestry and Agricultural Biotechnology Institute, University of Pretoria, South Africa; IMI = International Mycological Institute, CBI-Bioscience, Egham, U.K.; PD = culture collection, University of California, Davis, U.S.A.; and UCR = culture collection, University of California, Riverside, U.S.A.

${ }^{\mathrm{z}}$ ITS $=$ internal transcribed spacer, and TEF1- $\alpha=$ translation elongation factor 1- $\alpha$. Boldface type indicates ex-type specimens. 
morphologically similar to the description of $N$. nonquaesitum (Inderbitzin et al. 2010; Phillips et al. 2013).

Group 7, N. parvum. The colony developed dense filamentous mycelia that were primarily aerial, which initially were white and turned to light and dark gray to black. The pycnidia were usually simple or aggregated, of black color, and globose. The conidia were initially hyaline, aseptate, with granular content, fusiform, and with time, the conidia were biseptate with a light brown middle cell, of 15.7 to $29.1 \times 4.9$ to $10.9 \mu \mathrm{m}$ (Table 3 ). Ascomata were not observed. These isolates were morphologically similar to the description of N. parvum (Phillips et al. 2013).

Temperature effects on mycelial growth. The isolates in the groups of $D$. mutila, $N$. nonquaesitum, $D$. seriata, and $N$. parvum had similar mycelial growth in the range of 5 to $35^{\circ} \mathrm{C}$ and optimal mycelial growth at $25^{\circ} \mathrm{C}$. Isolates in the groups of $D$. iberica and $N$. australe grew at these same temperatures but had less mycelial growth at these temperatures. The isolate PALUC406M of $D$. pseudoseriata grew between 5 and $30^{\circ} \mathrm{C}$ with optimal mycelial growth at $25^{\circ} \mathrm{C}$. Additionally, isolate PALUC449F in the group of $L$. theobromae grew between 5 and $40^{\circ} \mathrm{C}$ with optimal mycelial growth between 25 and $35^{\circ} \mathrm{C}$ (Fig. 1).

DNA extraction, PCR amplification, and sequencing. The ITS1-5.8S-ITS2 region of 28 isolates of Botryosphaeriaceae family was amplified, obtaining 521- to 563-bp fragments. All sequences shared a 99 to $100 \%$ identity with published sequences of

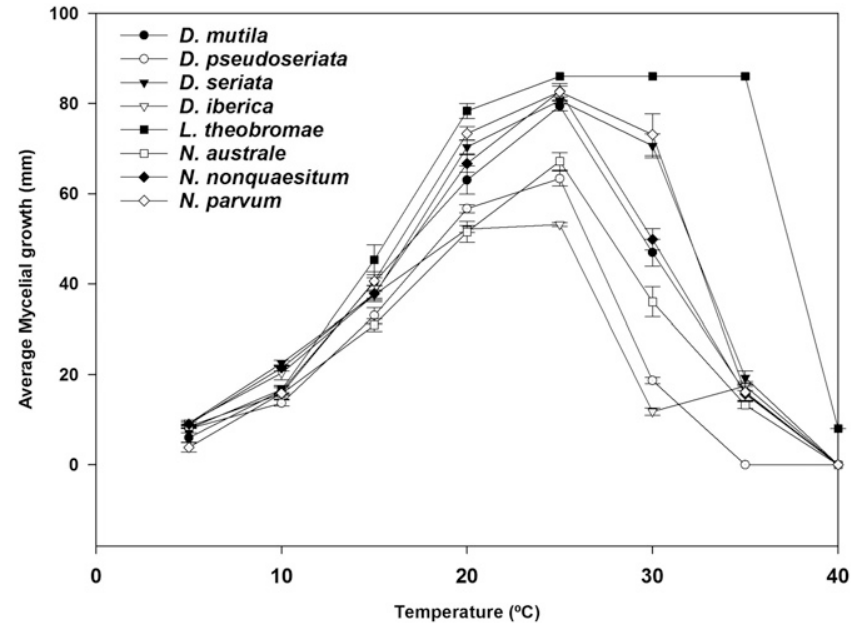

Fig. 1. Effects of temperature on the average mycelial growth $(\mathrm{mm})$ of Diplodia mutila, D. pseudoseriata, D. seriata, Dothiorella iberica, Lasiodiplodia theobromae, Neofusicoccum australe, $N$. nonquaesitum, and $N$. parvum. The average of the mycelial growth was derived from measurements of the colony diameter on the second and third days after inoculation on acidified potato dextrose agar. Vertical bars represent the standard error of the mean.

Table 3. Conidial measurements of Botryosphaeriaceae species obtained from avocado wood and fruit in Chile and their comparison with the type specimens of previous studies

\begin{tabular}{|c|c|c|c|c|}
\hline Species & Isolate $^{w}$ & Conidial size, $\mathrm{L} \times \mathrm{W}$; Mean $\pm \mathrm{SD}(\mu \mathrm{m})^{\mathrm{x}}$ & $\mathbf{L} / \mathbf{W}^{\mathbf{y}}$ & Source \\
\hline Diplodia mutila & CBS 112553 & 27.4 to $23.5 \times 14.3$ to $12.4 ; 25.4 \pm 1.0 \times 13.4 \pm 0.5$ & 1.9 & Alves et al. (2004) \\
\hline D. mutila & PALUC1M & 26.9 to $20.8 \times 14.2$ to $9.4 ; 24.2 \pm 1.3 \times 12.2 \pm 1.1$ & 2.0 & This study \\
\hline D. mutila & PALUC18M & 29.5 to $20.6 \times 14.3$ to $10.6 ; 25.8 \pm 1.9 \times 12.8 \pm 0.8$ & 2.0 & This study \\
\hline D. mutila & PALUC45F & 30.3 to $20.9 \times 17.9$ to $10.3 ; 23.9 \pm 2.1 \times 13.6 \pm 1.5$ & 1.8 & This study \\
\hline D. mutila & PALUC451F & 29.8 to $22.1 \times 14.5$ to $10.2 ; 25.4 \pm 1.6 \times 12.5 \pm 0.9$ & 2.0 & This study \\
\hline D. pseudoseriata & CBS 124906 & 30.5 to $23.0 \times 14.0$ to $10.0 ; \mathrm{NA}^{\mathrm{z}}$ & NA & Perez et al. (2010) \\
\hline D. pseudoseriata & PALUC406M & 30.5 to $24.9 \times 13.3$ to $9.8 ; 27.3 \pm 1.2 \times 11.4 \pm 0.7$ & 2.4 & This study \\
\hline D. seriata & CBS 112555 & 28.0 to $21.5 \times 15.5$ to $11.0 ; 24.9 \pm 1.9 \times 12.9 \pm 1.1$ & 1.9 & Phillips et al. (2013) \\
\hline D. seriata & PALUC14M & 28.6 to $20.9 \times 13.4$ to $8.8 ; 24.1 \pm 1.8 \times 10.4 \pm 1.1$ & 2.3 & This study \\
\hline D. seriata & PALUC404M & 32.3 to $20.2 \times 12.5$ to $9.4 ; 25.0 \pm 2.2 \times 11.2 \pm 0.8$ & 2.2 & This study \\
\hline D. seriata & PALUC10F & 26.8 to $18.8 \times 11.9$ to $7.7 ; 22.2 \pm 1.7 \times 9.7 \pm 0.8$ & 2.3 & This study \\
\hline D. seriata & PALUC426F & 25.9 to $20.9 \times 12.4$ to $10.0 ; 23.6 \pm 1.6 \times 10.9 \pm 0.8$ & 2.2 & This study \\
\hline D. seriata & PALUC455F & 25.2 to $20.2 \times 14.2$ to $9.1 ; 22.3 \pm 1.3 \times 11.2 \pm 1.0$ & 2.0 & This study \\
\hline D. seriata & PALUC467F & 24.9 to $17.6 \times 12.0$ to $8.3 ; 21.8 \pm 1.5 \times 10.5 \pm 0.8$ & 2.1 & This study \\
\hline Dothiorella iberica & CBS 115041 & 28.6 to $17.2 \times 16.0$ to $8.1 ; 23.2 \pm 1.9 \times 10.9 \pm 1.2$ & 2.2 & Phillips et al. (2005) \\
\hline D. iberica & PALUC3M & 28.8 to $23.1 \times 13.7$ to $8.5 ; 26.1 \pm 1.5 \times 10.2 \pm 0.9$ & 2.6 & This study \\
\hline D. iberica & PALUC399M & 27.9 to $22.7 \times 11.7$ to $8.9 ; 25.1 \pm 1.1 \times 10.5 \pm 0.6$ & 2.4 & This study \\
\hline D. iberica & PALUC7F & 28.7 to $22.7 \times 12.8$ to $9.9 ; 25.7 \pm 1.4 \times 11.3 \pm 0.6$ & 2.3 & This study \\
\hline Lasiodiplodia theobromae & CBS 164.96 & 32.5 to $19.0 \times 18.5$ to $12.0 ; 26.2 \pm 2.6 \times 14.2 \pm 1.2$ & 1.9 & Phillips et al. (2013) \\
\hline L. theobromae & PALUC449F & 26.2 to $16.7 \times 14.5$ to $11.1 ; 20.9 \pm 2.4 \times 12.7 \pm 0.8$ & 1.7 & This study \\
\hline Neofusicoccum australe & CMW 6837 & 30.0 to $18.0 \times 7.5$ to $5.0 ; 24.7 \times 5.1$ & 4.8 & Phillips et al. (2013) \\
\hline N. australe & PALUC439F & 24.1 to $17.7 \times 12.8$ to $9.4 ; 21.7 \pm 1.9 \times 10.5 \pm 0.9$ & 2.1 & This study \\
\hline N. australe & PALUC454F & 29.9 to $19.9 \times 13.6$ to $8.5 ; 24.9 \pm 1.9 \times 10.9 \pm 0.9$ & 2.3 & This study \\
\hline N. australe & PALUC474F & 29.6 to $22.8 \times 12.3$ to $6.9 ; 25.2 \pm 1.8 \times 8.8 \pm 1.6$ & 2.9 & This study \\
\hline N. australe & PALUC490F & 23.3 to $17.9 \times 9.6$ to $6.2 ; 20.5 \pm 1.3 \times 8.1 \pm 0.8$ & 2.6 & This study \\
\hline N. nonquaesitum & PD484 & 29.0 to $17.0 \times 10.5$ to $5.5 ; 23.2 \times 7.6$ & 3.1 & Phillips et al. (2013) \\
\hline N. nonquaesitum & PALUC4M & 31.7 to $23.0 \times 9.4$ to $5.3 ; 27.0 \pm 1.8 \times 7.3 \pm 0.7$ & 3.7 & This study \\
\hline N. nonquaesitum & PALUC407M & 27.4 to $18.7 \times 8.5$ to $4.9 ; 23.9 \pm 1.9 \times 6.5 \pm 0.8$ & 3.7 & This study \\
\hline N. parvum & ATCC 58191 & 24.0 to $12.0 \times 10.0$ to $4.0 ; 17.1 \pm 2.1 \times 5.5 \pm 0.8$ & 3.2 & Phillips et al. (2013) \\
\hline N. parvum & PALUC16M & 26.4 to $16.5 \times 9.7$ to $6.1 ; 21.2 \pm 1.9 \times 8.2 \pm 0.9$ & 2.6 & This study \\
\hline N. parvum & PALUC411M & 24.6 to $18.8 \times 8.8$ to $6.5 ; 21.2 \pm 1.3 \times 7.7 \pm 0.6$ & 2.8 & This study \\
\hline N. parvum & PALUC6F & 23.1 to $15.7 \times 8.7$ to $4.9 ; 20.2 \pm 1.6 \times 7.2 \pm 0.8$ & 2.8 & This study \\
\hline N. parvum & PALUC44F & 22.4 to $17.7 \times 9.6$ to $5.9 ; 19.9 \pm 1.1 \times 7.8 \pm 0.7$ & 2.6 & This study \\
\hline N. parvum & PALUC415F & 28.6 to $17.9 \times 10.9$ to $6.4 ; 21.1 \pm 1.9 \times 8.0 \pm 0.9$ & 2.6 & This study \\
\hline N. parvum & PALUC470F & 23.4 to $16.1 \times 9.1$ to $5.1 ; 19.4 \pm 1.4 \times 7.3 \pm 0.8$ & 2.7 & This study \\
\hline N. parvum & PALUC496F & 29.1 to $19.5 \times 9.8$ to $6.6 ; 23.2 \pm 2.3 \times 8.2 \pm 0.8$ & 2.9 & This study \\
\hline
\end{tabular}

${ }^{w}$ Measured data of the ex-type is in boldface.

${ }^{x} \mathrm{~L} \times \mathrm{W}=$ maximum to minimum length $\times$ maximum to minimum width; average \pm standard deviation (SD) length by average \pm SD width.

${ }^{\mathrm{y}} \mathrm{L} / \mathrm{W}=$ average length/average width.

${ }^{\mathrm{z}} \mathrm{NA}=$ not available. 
Botryosphaeriaceae species deposited in GenBank (Table 2). However, the isolates PALUC3M, PALUC399M, and PALUC7F, which were morphologically identified as D. iberica, showed $99 \%$ identity ( $95 \%$ query cover) with GenBank sequences of $D$. iberica and $D$. sarmentorum (Table 2).

The partial amplification of the TEF1- $\alpha$ sequence generated fragments of 251 to $322 \mathrm{bp}$, and BLAST analyses revealed 95 to $100 \%$ identity with published sequences of Botryosphaeriaceae species deposited in GenBank (Table 2). Again, isolates PALUC3M, PALUC399M, and PALUC7F had 88 to $89 \%$ identity (99 to $100 \%$ query cover) with GenBank sequences of $D$. iberica and $97 \%$ identity (87\% query cover) with GenBank sequences of $D$. sarmentorum (Table 2). All the ITS and TEF1- $\alpha$ sequences obtained in this study were deposited in GenBank (Table 1).

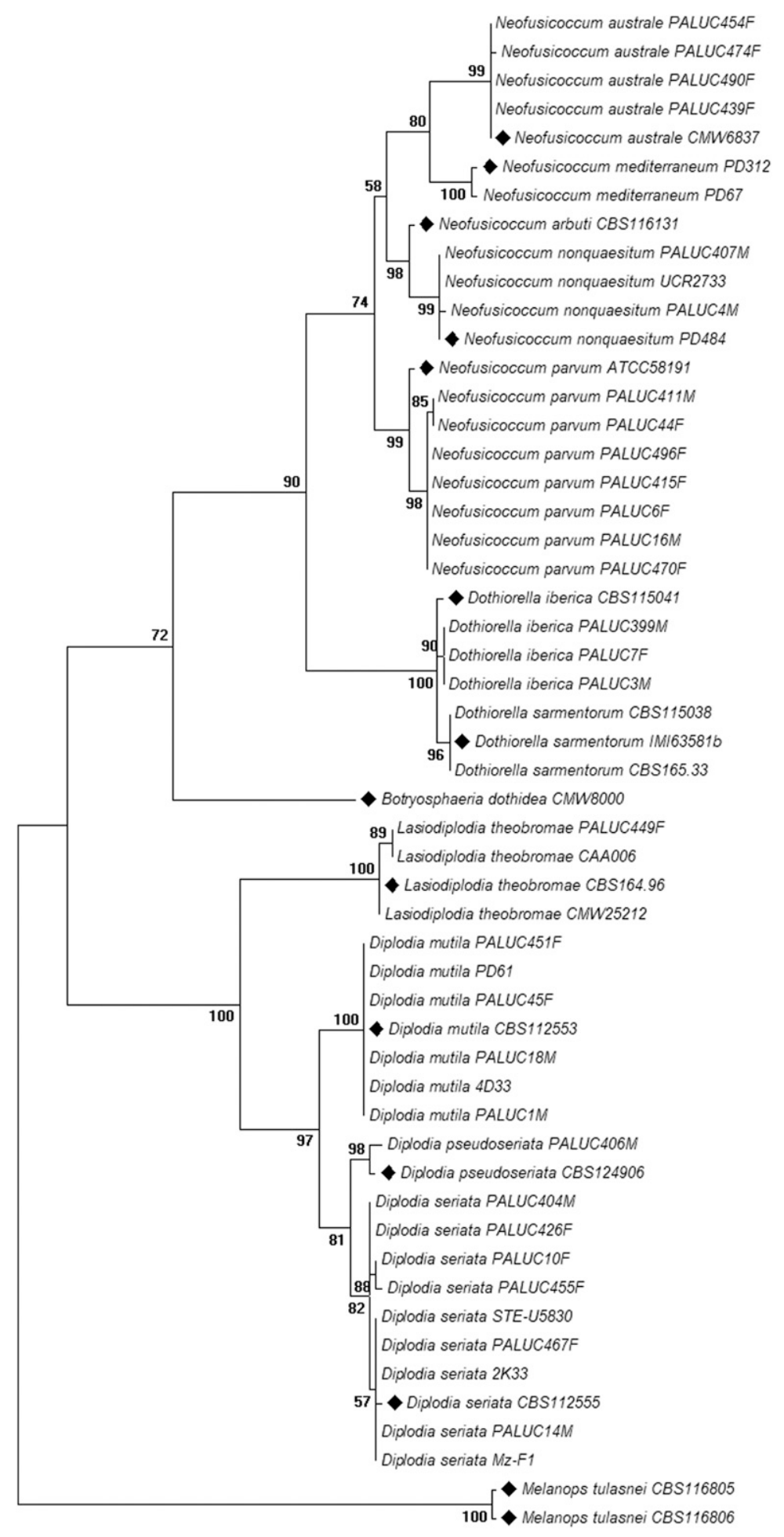

10

Fig. 2. One of the 10 most parsimonious phylogenetic trees obtained from the combined ITS and EF1- $\alpha$ datasets. Bootstrap values of 1,000 bootstrap replications are indicated at each node. Black square indicates type specimens, and "PALUC" denotes isolates from avocado wood and fruit in this study. CBS116805 and CBS116806 (Melanops tulasnei) were added as an outgroup. 
Phylogenetic analysis. The separate phylogenetic analyses of the ITS and TEF1- $\alpha$ sequences clustered Botryosphaeriaceae isolates obtained in this study with clades of D. mutila, D. pseudoseriata, $D$. seriata, $L$. theobromae, $N$. australe, $N$. nonquaesitum, and $N$. parvum (data not shown). The isolates PALUC3M, PALUC399M, and PALUC7F in their phylogenetic analysis of the ITS sequences clustered with clades of $D$. iberica (95\% bootstrap support). Additionally, the phylogenetic analysis of the TEF1- $\alpha$ sequences showed isolates clustered with the clade of $D$. iberica ( $91 \%$ bootstrap support) (data not shown).

The partition homogeneity test indicated that there was not a significant difference $(P=0.12)$ between the ITS and TEF1- $\alpha$ datasets. Therefore, a concatenated analysis was performed. The combined ITS and TEF1- $\alpha$ dataset included 53 taxa of 607 total characters with 324 parsimonious informative characters. The maximum parsimony analysis returned the seven most parsimonious trees with the following scores: $\mathrm{CI}=0.75, \mathrm{RI}=0.96$, and $\mathrm{RCI}=0.72$. The phylogenetic analysis of the combined ITS and TEF1- $\alpha$ dataset from Botryosphaeriaceae species produced a phylogenetic tree with two primary clades. In the first clade ( $72 \%$ bootstrap support), isolates obtained in this study clustered as $N$. australe, $N$. nonquaesitum, $N$. parvum, and $D$. iberica. The second clade (100\% bootstrap support) of isolates obtained in this study clustered with clades of $L$. theobromae, D. mutila, D. pseudoseriata, and D. seriata (Fig. 2). Isolates of D. mutila (PALUC18M, PALUC451F), D. pseudoseriata (PALUC406M), D. seriata (PALUC404M, PALUC10F, PALUC467F), D. iberica (PALUC399M, PALUC7F), L. theobromae (PALUC449F), N. australe (PALUC439F, PALUC454F), N. nonquaesitum (PALUC4M), and N. parvum (PALUC16M, PALUC6F, PALUC496F) were deposited as living cultures in the Chilean Microbial Genetic Resources Collection (www.cchrgm.cl).

Pathogenicity testing. Pathogenicity testing on young trees. All the isolates tested were pathogenic on 1-year-old avocado plants. Brown gummy exudate and necrosis developed in the vascular system 3 weeks after inoculation. In some cases, wilted leaves near the site of inoculation were observed, and fruiting bodies were observed in the stems inoculated with $D$. mutila, $N$. nonquaesitum, and $N$. parvum. The $N$. nonquaesitum isolates were the most virulent isolates $(P=0.0184)$, producing vascular lesions $117.5 \mathrm{~mm}$ in diameter on average. The $N$. parvum and $D$. pseudoseriata isolates were the second most virulent isolates, causing necrotic lesions above $80 \mathrm{~mm}$ in diameter. D. mutila, D. iberica, and D. seriata isolates were

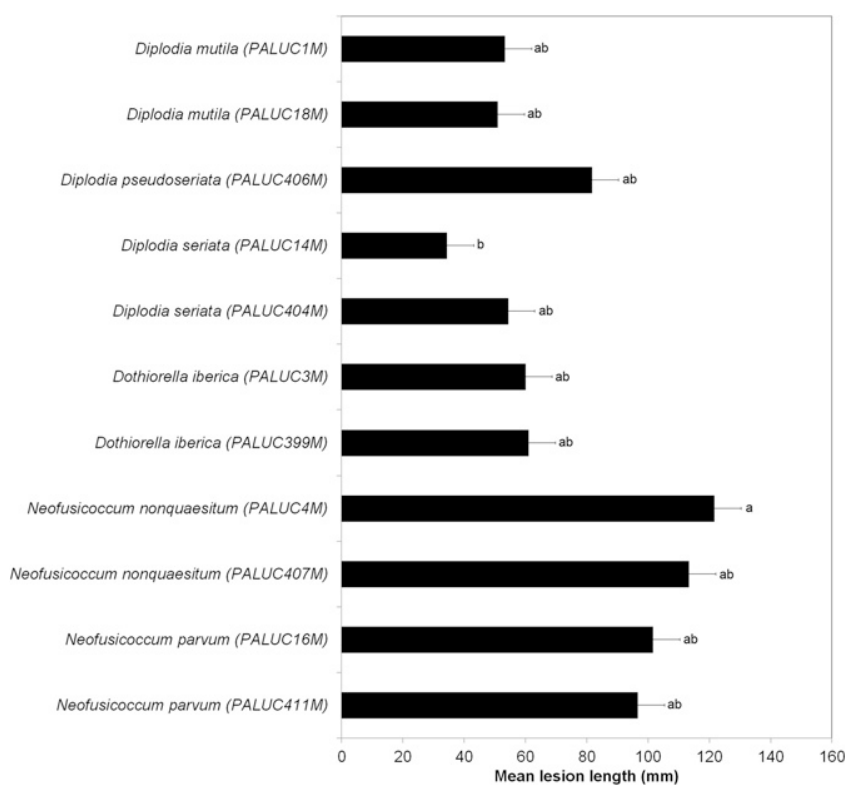

Fig. 3. Mean lesion length $(\mathrm{mm})$ caused by Botryosphaeriaceae species in Hass avocado plants 8 weeks after inoculation. Horizontal bars represent the standard error of the mean. Mean lesion length values followed by the same letter are not significantly different according to Tukey's test $(P=0.05)$. less virulent with mean lesion sizes less than or close to $60 \mathrm{~mm}$ in diameter (Fig. 3). All isolates were successfully reisolated from symptomatic inoculated plants and reidentified based on their cultural and morphological features. Control plants remained symptomless, and isolates of Botryosphaeriaceae species were not detected from the pieces of stem on APDA, thus fulfilling Koch's postulates.

Pathogenicity testing on harvested fruit. Isolates of Botryosphaeriaceae species were pathogenic on Hass avocado fruits, producing black lesions near the peduncle union zone with light brown and softening of the pulp. In certain cases, there were cavities in the pulp with vascular browning. Additionally, abundant white-gray mycelia grew near the site of inoculation. L. theobromae isolate PALUC449F was the most virulent $(P<0.0001)$, producing average vascular lesions of $67.5 \mathrm{~mm}$ in diameter. $N$. parvum (isolates PALUC6F, PALUC44F, PALUC415F, PALUC470F, PALUC496F), N. australe (isolates PALUC439F, PALUC454F, PALUC474F, PALUC490F), D. mutila (isolates PALUC45F, PALUC451F), and D. seriata (isolates PALUC10F, PALUC426F, PALUC467F) were the second most virulent isolates, causing lesions greater than or close to $40 \mathrm{~mm}$ in diameter. In contrast, the isolates of $D$. seriata (PALUC455F) and D. iberica (PALUC7F) were significantly less virulent $(P<0.0001)$ (Fig. 4). All isolates were reisolated in APDA from tissue obtained from the margins of decay in the pulp of inoculated fruits with $100 \%$ fungal recovery. The isolates were reidentified based on their cultural and morphological features. Control fruits remained symptomless, and isolates of Botryosphaeriaceae species were not reisolated from pieces of pulp on APDA. Therefore, Koch's postulates were completed.

Pathogenicity testing on stored fruit. Fruit stored for 15 days or more showed chilling injury, such as vascular and mesocarp browning. On inoculated fruit, a superficial mycelial growth on the peel and internal necrosis of the pulp and vascular tissue that extended from the inoculation site to the rest of the fruit was observed. Analysis of the average lesion diameter indicated significant differences between the isolates of the same species and isolates of distinct species when they were inoculated in fruits that were stored for 15 and 30 days at $5^{\circ} \mathrm{C}(P<0.0001)$. However, there were no differences on fruits maintained for 45 days under such conditions (Table 4). On fruits that were incubated for 15 days at $5^{\circ} \mathrm{C}$, the most severe damage was caused by $N$. parvum (isolates PALUC470F and PALUC415F), L. theobromae (isolate PALUC449F), D. seriata (isolate PALUC426F), D. mutila (isolates PALUC45F and PALUC451F),

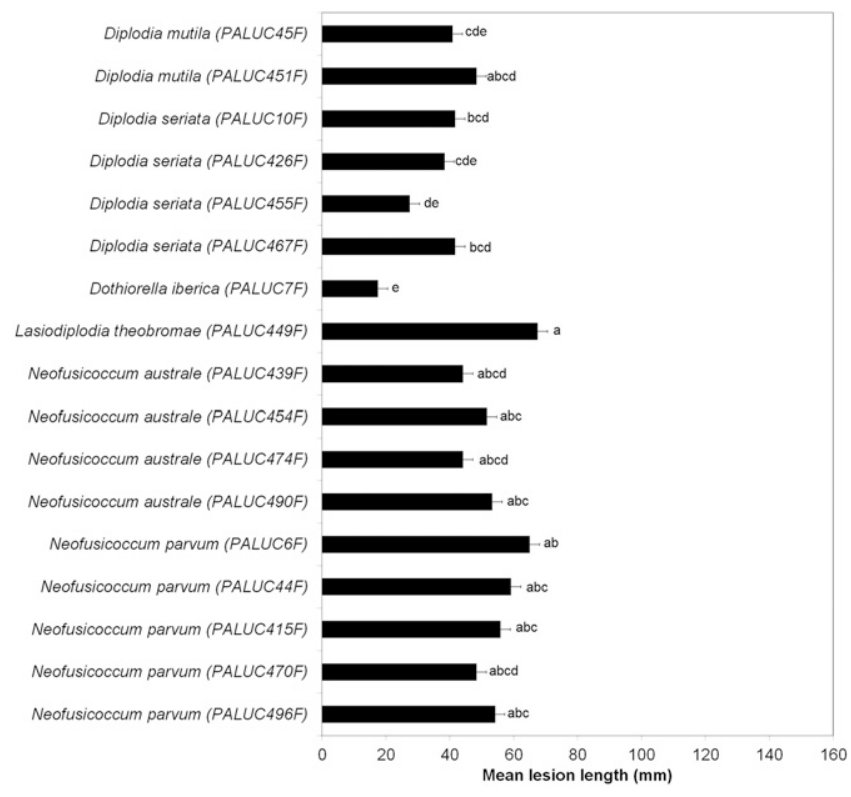

Fig. 4. Mean lesion length $(\mathrm{mm})$ caused by Botryosphaeriaceae species in Hass avocado fruit incubated for 10 days at $20^{\circ} \mathrm{C}$ after inoculation. Horizontal bars represent the standard error of the mean. Mean lesion length values followed by the same letter are not significantly different according to Tukey's test $(P=0.05)$. 
and $N$. australe (isolates PALUC439F and PALUC490F), with lesions greater than or close to $50 \mathrm{~mm}$ in diameter. Additionally, isolates of D. iberica (isolate PALUC7F) and $N$. parvum (isolate PALUC496F) had similar average lesion diameters (approximately $20 \mathrm{~mm}$ ). On fruits stored for 30 days at $5^{\circ} \mathrm{C}$ plus 7 days at $20^{\circ} \mathrm{C}$, the most severe damage was caused by isolates of $D$. mutila (isolates PALUC45F and PALUC451F), $N$. parvum (isolate PALUC496F), and D. seriata (isolate PALUC455F), with lesions greater than or close to $50 \mathrm{~mm}$ in diameter. Conversely, D. iberica (isolate PALUC7F) caused lesions of $26 \mathrm{~mm}$ in diameter on average. Control fruits developed small necrotic lesions around the inoculation site, which were associated with inoculation damage. There were significant differences between isolates and storage times $(P<0.0001)$. Similarly, the interaction between these factors was significant $(P<0.0001)$. The fungal recovery was $100 \%$ from symptomatic inoculated fruit for each storage time. The isolates were reidentified based on their cultural and morphological features.

\section{Discussion}

In this study, eight species in the family Botryosphaeriaceae were identified. Of these, Diplodia mutila, D. pseudoseriata, D. seriata, Dothiorella iberica, $N$. nonquaesitum, and $N$. parvum were demonstrated to be pathogenic to Hass avocado plants. In addition, $D$. mutila, D. seriata, D. iberica, L. theobromae, $N$. australe, and $N$. parvum were demonstrated to be pathogenic and cause stem end rot on Hass avocado fruit. In Chile, $N$. australe had been previously reported in avocado trees (Auger et al. 2013) and fruits (Montealegre et al. 2016). To our knowledge, this is the first report of D. mutila, $D$. seriata, $D$. iberica, $N$. nonquaesitum, and $N$. parvum associated with branch canker and dieback in avocado in Chile. Additionally, it has not been previously reported that $D$. mutila, $D$. seriata, D. iberica, L. theobromae, and $N$. parvum were associated with stem end rot of avocados in Chile. Therefore, this study is also the first to report regarding these pathogens in Chilean avocado trees and fruit.

The identification of the isolates obtained in this study suggest that the identification of Botryosphaeriaceae species is only possible with both morphological characterization of colony growth and sequence comparison of the ITS and TEF1- $\alpha$ gene regions, which were previously described in several taxonomic reports (Crous et al. 2006; Dissanayake et al. 2016; Phillips et al. 2013; Slippers et al. 2017).

The morphological features allowed the identification of the isolates obtained in this study as D. mutila, D. seriata, L. theobromae, $N$. australe, and N. parvum. However, the isolate PALUC406M showed morphological features similar to $D$. seriata but had different conidial dimensions and showed better mycelial growth at different temperatures, features that were similar to data reported by Pérez et al. (2010). The BLAST analysis and the separate and combined phylogenetic analyses of the ITS and TEF1- $\alpha$ gene regions allowed identification of this isolate as $D$. pseudoseriata.

The morphological identities were confirmed with the combined phylogenetic analysis of ITS and TEF1- $\alpha$ gene regions, which allowed distinction of species most closely related phylogenetically, such as $N$. nonquaesitum from $N$. arbuti and $D$. iberica from $D$. sarmentorum (Phillips et al. 2013). The isolates PALUC4M and PALUC407M, when compared with the published data of $N$. nonquaesitum and $N$. arbuti (Inderbitzin et al. 2010; Phillips et al. 2013) were similar to $N$. nonquaesitum in the dimensions of their conidia, which is a characteristic that distinguishes $N$. nonquaesitum from $N$. arbuti (Phillips et al. 2013). Similarly, the phylogenetic analysis clustered these isolates with the clade of $N$. nonquaesitum, which included the specimen type and isolates obtained by Carrillo et al. (2016) in avocado wood with branch canker and dieback. Likewise, the isolates PALUC3M, PALUC399M, and PALUC7F, when compared with the data published on D. iberica and D. sarmentorum (Phillips et al. 2005) were more similar to D. iberica, because the average size and maximum length of the conidia were longer than the conidial size of D. sarmentorum, which are characteristics that distinguish both species (Phillips et al. 2013). This distinction was supported by the combined ITS and TEF1- $\alpha$ phylogenetic analysis, which clustered these isolates with clades of $D$. iberica that included the specimen type (Phillips et al. 2005).

In this study, isolates of $D$. seriata, $D$. iberica, $N$. nonquaesitum, and $N$. parvum were detected in samples from avocado orchards

Table 4. Pathogenicity study of Botryosphaeriaceae species on Hass avocado fruit stored for 15,30 , or 45 days at $5^{\circ} \mathrm{C}$, followed by incubation for 10 days at $20^{\circ} \mathrm{C}$ in a normal atmosphere

\begin{tabular}{|c|c|c|c|c|c|c|c|c|c|c|c|c|}
\hline \multirow[b]{2}{*}{ Species/isolate } & \multicolumn{12}{|c|}{ Mean lesion length $(\mathrm{mm})^{\mathrm{z}}$} \\
\hline & \multicolumn{3}{|c|}{15 days at $5^{\circ} \mathrm{C}$} & \multicolumn{3}{|c|}{30 days at $5^{\circ} \mathrm{C}$} & \multicolumn{3}{|c|}{45 days at $5^{\circ} \mathrm{C}$} & \multicolumn{3}{|c|}{ Mean } \\
\hline \multicolumn{13}{|l|}{ Diplodia mutila } \\
\hline PALUC45F & \multicolumn{3}{|c|}{$46.8 \mathrm{ab}$} & \multicolumn{3}{|c|}{$53.5 \mathrm{a}$} & \multicolumn{3}{|c|}{$48.1 \mathrm{a}$} & \multicolumn{3}{|c|}{$49.4 \mathrm{a}$} \\
\hline PALUC451F & \multicolumn{3}{|c|}{$44.5 \mathrm{ab}$} & \multicolumn{3}{|c|}{$43.5 \mathrm{ab}$} & \multicolumn{3}{|c|}{$53.2 \mathrm{a}$} & \multicolumn{3}{|c|}{$47.0 \mathrm{a}$} \\
\hline \multicolumn{13}{|l|}{ D. seriata } \\
\hline PALUC426F & & \multicolumn{3}{|c|}{$36.5 \mathrm{bcd}$} & \multicolumn{3}{|c|}{$59.1 \mathrm{a}$} & \multicolumn{3}{|c|}{$48.5 \mathrm{a}$} \\
\hline PALUC455F & \multicolumn{2}{|r|}{$34.9 \mathrm{bc}$} & & \multicolumn{3}{|c|}{$47.5 \mathrm{ab}$} & \multicolumn{3}{|c|}{$58.1 \mathrm{a}$} & \multicolumn{3}{|c|}{$46.7 \mathrm{a}$} \\
\hline \multicolumn{13}{|l|}{ Dothiorella iberica } \\
\hline PALUC7F & \multicolumn{3}{|c|}{$17.0 \mathrm{~d}$} & \multicolumn{3}{|c|}{$26.0 \mathrm{~d}$} & \multicolumn{3}{|c|}{$46.3 \mathrm{a}$} & \multicolumn{3}{|c|}{$29.7 \mathrm{~b}$} \\
\hline \multicolumn{13}{|c|}{ Lasiodiplodia theobromae } \\
\hline PALUC449F & & $53.0 \mathrm{ab}$ & & & 35. & & & 59.3 & & & $49.1 \mathrm{a}$ & \\
\hline Neofusicoccum austral & & & & & & & & & & & & \\
\hline PALUC439F & & $40.8 \mathrm{~b}$ & & & 36.0 & & & 64.8 & & & $47.2 \mathrm{a}$ & \\
\hline PALUC490F & & $42.0 \mathrm{ab}$ & & & 35.0 & & & 54. & & & $43.6 \mathrm{a}$ & \\
\hline N. parvum & & & & & & & & & & & & \\
\hline PALUC6F & & $34.5 \mathrm{c}$ & & & 34.0 & & & 55. & & & $41.1 \mathrm{a}$ & \\
\hline PALUC415F & & $55.5 \mathrm{a}$ & & & 31.0 & & & 53. & & & $46.7 \mathrm{a}$ & \\
\hline PALUC470F & & $50.0 \mathrm{ab}$ & & & 39.0 & & & 61. & & & $50.0 \mathrm{a}$ & \\
\hline PALUC496F & & $21.5 \mathrm{~d}$ & & & 44.0 & & & 66. & & & $43.8 \mathrm{a}$ & \\
\hline Control & & $7.5 \mathrm{~d}$ & & & 19.5 & & & 24. & & & $17.1 \mathrm{c}$ & \\
\hline Mean & & $38.3 \mathrm{~b}$ & & & 36.5 & & & 54. & & & & \\
\hline Analysis of variance & df & $\boldsymbol{F}$ & $P$ & df & $\boldsymbol{F}$ & $P$ & df & $\boldsymbol{F}$ & $P$ & df & $F$ & $P$ \\
\hline Isolates (I) & 12 & 17.8 & $<0.0001$ & 12 & 6.5 & $<0.0001$ & 12 & 5.8 & $<0.0001$ & 12 & 18.3 & $<0.0001$ \\
\hline Time $(\mathrm{T})$ & & & & & & & & & & 2 & 80.4 & $<0.0001$ \\
\hline $\mathrm{I} \times \mathrm{T}$ & & & & & & & & & & 24 & 4.9 & $<0.0001$ \\
\hline
\end{tabular}

${ }^{\mathrm{z}}$ Data are the average of five replicates. Means followed by same letters are not significantly different $(P=0.05)$ according to Tukey's test. Mean lesion lengths (mm) of fruit maintained for 15,30 , and 45 days at $5^{\circ} \mathrm{C}$ plus 10 days at $20^{\circ} \mathrm{C}$. 
located in different climatic zones. In this sense, McDonald and Eskalen (2011) indicated that climatic factors do not provide an explanation for the distribution of Botryosphaeriaceae species, because their study detected the same species in northern and southern states of the United States. Under natural conditions, one would expect that the distribution of these species would be localized, because studies of spore dispersal indicated that their spread is mainly associated with splashing water owing to rainfall or irrigation and wind dispersal (Eskalen et al. 2013; Úrbez-Torres et al. 2010; Valencia et al. 2015). Mehl et al. (2017a, b) indicated that human-assisted dispersal has played a significant role in the worldwide distribution of Botryosphaeriaceae species associated with agriculture, probably because these fungi persist endophytically in infected but asymptomatic plant material that is sold and transported across country boundaries (Slippers and Wingfield 2007).

Botryosphaeria branch canker and dieback are important problems in Chilean viticulture, where D. mutila, D. seriata, $N$. australe, and N. parvum were detected (Auger et al. 2004; Besoain et al. 2013; Díaz et al. 2013; Morales et al. 2012; Valencia et al. 2015). Similarly, D. mutila was detected in the wood of English walnut (Díaz et al. 2018), $N$, arbuti, N. australe, and N. parvum in the wood of blueberry (Espinoza et al. 2009), N. parvum in kiwi plants (Díaz et al. 2016), and B. dothidea in apple trees (Latorre and Toledo 1984). In addition, D. seriata was reported to cause black rot in apple fruits (Cáceres et al. 2016).

In this study, $N$. parvum, D. mutila, D. seriata, and D. iberica were obtained from samples of avocado wood and fruit. These results confirmed reports of Twizeyimana et al. (2013) and Guarnaccia et al. (2016) that these pathogens, localized endophytically in wood, could infect fruit. Their results confirmed that stem end rot can be initiated by fungi causing branch canker. Additionally, it is important to consider that wounding is a prerequisite for infection of Botryosphaeriaceae species in wood (pruning wounds, frost damage, and grafting wounds) and fruit (infections of peduncle can be initiated during harvest) (Dann et al. 2013; Hartill and Everett 2002). Therefore, incorporating preharvest and postharvest management strategies, such as cultural practices that limit the dissemination of these pathogens or that decrease stress in avocado trees and fruit as well as effective fungicide applications, could reduce the development of branch canker, dieback, and the incidence of stem end rot (Dann et al. 2013; Hartill and Everett 2002; Menge and Ploetz 2003; Twizeyimana et al. 2013).

The pathogenicity results of this study indicated that the Botryosphaeriaceae species obtained from the Chilean orchards are pathogenic to Hass avocado. Similarly, $N$. nonquaesitum and $N$. parvum were the most virulent species, causing severe damage in the inner vascular tissue of the plant stem. These results were similar to reports of Carrillo et al. (2016) and McDonald et al. (2009), who also measured the length of vascular lesions. In addition, Slippers and Wingfield (2007) indicated that $N$. parvum and $N$. australe are considered to be the most damaging species in the Botryosphaeriaceae family. $D$. pseudoseriata also caused severe damage in avocado stems. This species was not previously reported to be associated with avocado branch cankers. Therefore, this is the first report of this pathogen causing branch canker and dieback in avocado in the world. The isolates of $D$. mutila, D. iberica, and D. seriata of this study had low virulence in avocado plants. These species are not considered to be common pathogens in avocado trees.

In pathogenicity tests of avocado fruit, isolates of $L$. theobromae, $N$. parvum, and N. australe caused severe damage to the pulp of fruit. Other studies indicated that these pathogenic species could cause stem end rot (Akgül et al. 2016; Twizeyimana et al. 2013), fruit rot (Garibaldi et al. 2012), and black spot (Molina-Gayosso et al. 2012 ) in avocado fruit. The isolates of D. mutila, D. iberica, and $D$. seriata had low virulence on avocado fruit. These species are not considered to be common pathogens in avocado fruit.

Avocados are usually stored at $5^{\circ} \mathrm{C}$ under normal atmospheric conditions before they are shipped overseas and distributed to consumers. However, the results of the pathogenicity tests on fruit stored for 15 to 45 days at $5^{\circ} \mathrm{C}$ under normal atmospheric conditions indicated that all fruits inoculated with Botryosphaeriaceae species developed symptoms of stem end rot. Additionally, these fruits were damaged by chilling injury, and this damage was highest on inoculated fruits and was most severe after 45 days in storage. These results indicate the importance of storing fruit at optimal conditions to reduce the impact of Botryosphaeriaceae infection in avocado fruit. Defilippi al. (2015) indicated that avocados should be stored under controlled conditions of temperature ( 4 to $5^{\circ} \mathrm{C}$ ), humidity $(90 \%), \mathrm{CO}_{2}(6 \%)$, and $\mathrm{O}_{2}(4 \%)$ to avoid changes that can alter the fruit.

In conclusion, this study identified and characterized the pathogenicity of species in the Botryosphaeriaceae family associated with branch canker, dieback, and stem end rot in avocado orchards located in the primary production region in Chile. This research provides information that can guide future research to study the epidemiology of these pathogens to establish effective prevention and control strategies, to limit the dissemination of these pathogens to the fruit, and to study adequate fruit storage conditions to prolong their postharvest life until they reach consumers.

\section{Acknowledgments}

We thank Alonso Retamales for his technical support in the field and laboratory, the producers and advisers who allowed us to examine their orchards, and the staff of our university laboratories for their technical assistance during the development of this research.

\section{Literature Cited}

Akgül, D. S., Awan, Q. N., Güler, P. G., and Önelge, N. 2016. First report of anthracnose and stem end rot diseases caused by Colletotrichum gloeosporioides and Neofusicoccum australe on avocado fruits in Turkey. Plant Dis. 100:1792.

Alves, A., Correia, A., Luque, J., and Phillips, A. J. L. 2004. Botryosphaeria corticola, sp. nov. on Quercus species, with notes and description of Botryosphaeria stevensii and its anamorph, Diplodia mutila. Mycologia 96: 598-613.

Alves, A., Correia, A., and Phillips, A. J. L. 2006. Multi-gene genealogies and morphological data support Diplodia cupressi sp. nov., previously recognized as $D$. pinea f. sp. cupressi, as a distinct species. Fungal Divers. 23:1-15.

Alves, A., Crous, P. W., Correia, A., and Phillips, A. J. L. 2008. Morphological and molecular data reveal cryptic speciation in Lasiodiplodia theobromae. Fungal Divers. 28:1-13.

Aly, A. H., Debbab, A., and Proksch, P. 2011. Fungal endophytes: Unique plant inhabitants with great promises. Appl. Microbiol. Biotechnol. 90:1829-1845.

Auger, J., Esterio, M., Ricke, G., and Pérez, I. 2004. Black dead arm and basal canker of Vitis vinifera cv. Red Globe caused by Botryosphaeria obtusa in Chile. Plant Dis. 88:1286.

Auger, J., Palma, F., Pérez, I., and Esterio, M. 2013. First report of Neofusicoccum australe (Botryosphaeria australis), as a branch dieback pathogen of avocado trees in Chile. Plant Dis. 97:842.

Besoain, X., Torres, C., Díaz, G. A., and Latorre, B. A. 2013. First report of Neofusicoccum australe associated with Botryosphaeria canker of grapevine in Chile. Plant Dis. 97:143.

Cáceres, M., Lolas, M., Gutierrez, M., Ferrada, E., and Díaz, G. A. 2016. Severe outbreak of black rot in apple fruit cv. Fuji caused by Diplodia seriata during pre-harvest in Maule Region, Chile. Plant Dis. 100:2333.

Carbone, I., and Kohn, L. M. 1999. A method for designing primer sets for speciation studies in filamentous ascomycetes. Mycologia 91:553-556.

Carrillo, J. D., Eskalen, A., Rooney-Latham, S., and Scheck, H. J. 2016. First report of Neofusicoccum nonquaesitum causing branch canker and dieback of avocado in California. Plant Dis. 100:1778.

Chanderbali, A. S., Soltis, D. E., Soltis, P. S., and Wolstenholme, B. N. 2013. Taxonomy and botany. Pages 31-50 in: The Avocado: Botany, Production and Uses. B. Schaffer, B. N. Wolstenholme, and A. W. Whiley, eds. CABI International Press, Wallingford, U.K.

Chen, S. F., Morgan, D. P., Hasey, J. K., Anderson, K., and Michailides, T. J. 2014. Phylogeny, morphology, distribution, and pathogenicity of Botryosphaeriaceae and Diaporthaceae from English walnut in California. Plant Dis. 98:636-652.

Crous, P. W., Slippers, B., Wingfield, M. J., Rheeder, J., Marasas, W. F., Philips, A. J., and Groenewald, J. Z. 2006. Phylogenetic lineages in the Botryosphaeriaceae. Stud. Mycol. 55:235-253.

Damm, U., Crous, P. W., and Fourie, P. H. 2007. Botryosphaeriaceae as potential pathogens of Prunus species in South Africa, with descriptions of Diplodia africana and Lasiodiplodia plurivora sp. nov. Mycologia 99:664-680.

Dann, E. K., Ploetz, R. C., Coates, L. M., and Pegg, K. G. 2013. Foliar, fruit and soilborne diseases. Pages 380-422 in: The Avocado: Botany, Production and Uses. B. Schaffer, B. N. Wolstenholme, and A. W. Whiley, eds. CABI International Press, Wallingford, U.K.

Darvas, J. M., and Kotzé, J. M. 1987. Fungi associated with pre-and postharvest diseases of avocado fruit at Westfalia Estate, South Africa. Phytophylactica 19:83-85. 
Defilippi, B., Ferreyra, R., and Rivera, S. 2015. Optimización de la calidad de palta 'Hass': Herramientas para enfrentar nuevos desafíos. Instituto de Investigaciones Agropecuarias, Santiago, Chile.

Díaz, G., Latorre, B., Lolas, M., and Ferrada, E. 2018. First report of Diplodia mutila causing branch dieback of English walnut cv. Chandler in the Maule Region, Chile. Plant Dis. 102:1451.

Díaz, G., Lolas, M., Latorre, B., Ferrada, E., and Zoffoli, J. 2016. Characterization of Diaporthe spp. Cadophora malorum and Neofusicoccum parvum causing cordon dieback in kiwi plant and their chemical control in Chile. (Abstr.) Phytopathology 106(Suppl. 4):S4.1.

Díaz, G. A., Auger, J., Besoain, X., Bordeu, E., and Latorre, B. A. 2013. Prevalence and pathogenicity of fungi associated with grapevine trunk diseases in Chilean vineyards. Cienc. Inv. Agr. 40:327-339.

Dissanayake, A. J., Phillips, A. J. L., Li, X. H., and Hyde, K. D. 2016. Botryosphaeriaceae: Current status of genera and species. Mycosphere 7:1001-1073.

Eskalen, A., Faber, B., and Bianchi, M. 2013. Spore trapping and pathogenicity of fungi in the Botryosphaeriaceae and Diaporthaceae associated with avocado branch canker in California. Plant Dis. 97:329-332.

Espinoza, J. G., Briceño, E. X., Chávez, E. R., Úrbez-Torres, J., and Latorre, B. A. 2009. Neofusicoccum spp. associated with stem canker and dieback of blueberry in Chile. Plant Dis. 93:1187-1194.

Filatov, D. A. 2002. ProSeq: A software for preparation and evolutionary analysis of DNA sequence data sets. Mol. Ecol. Resour. 2:621-624.

Garibaldi, A., Bertetti, D., Amatulli, M. T., Cardinale, J., and Gullino, M. L. 2012. First report of postharvest fruit rot in avocado (Persea americana) caused by Lasiodiplodia theobromae in Italy. Plant Dis. 96:460.

Guarnaccia, V., Vitale, A., Cirvilleri, G., Aiello, D., Susca, A., Epifani, F., Perrone, G., and Polizzi, G. 2016. Characterization and pathogenicity of fungal species associated with branch cankers and stem-end rot of avocado in Italy. Eur. J. Plant Pathol. 146:963-976.

Hartill, W. F. T., and Everett, K. R. 2002. Inoculum sources and infection pathways of pathogens causing stem-end rots of 'Hass' avocado (Persea americana). N. Z. J. Crop Hortic. Sci. 30:249-260.

Hopkirk, G., White, A., Beever, D. J., and Forbes, S. K. 1994. Influence of postharvest temperatures and the rate of fruit ripening on internal postharvest rots and disorders of New Zealand 'Hass' avocado fruit. N. Z. J. Crop Hortic. Sci. 22:305-311

Inderbitzin, P., Bostock, R. M., Trouillas, F. P., and Michailides, T. J. 2010. A six-locus phylogeny reveals high species diversity in Botryosphaeriaceae from California almond. Mycologia 102:1350-1368.

Johnson, G. I., and Kotzé, J. M. 1994. Avocado. Pages 71-84 in: Compendium of Tropical Fruit Diseases. R. C. Ploetz, G. A. Zentmyer, W. T. Nishijima, K. G. Rohrbach, and H. D. Ohr, eds. APS Press, St. Paul, MN.

Larkin, M. A., Blackshields, G., Brown, N. P., Chenna, R., McGettigan, P. A., McWilliam, H., Valentin, F., Wallace, I. M., Wilm, A., Lopez, R., Thompson, J. D., Gibson, T. J., and Higgins, D. G. 2007. Clustal W and Clustal X version 2.0. Bioinformatics 23:2947-2948.

Latorre, B. A., and Toledo, M. V. 1984. Occurrence and relative susceptibility of apple cultivars to Botryosphaeria dothidea canker in Chile. Plant Dis. 68:36-39.

McDonald, V., and Eskalen, A. 2011. Botryosphaeriaceae species associated with avocado branch cankers in California. Plant Dis. 95:1465-1473.

McDonald, V., Lynch, S., and Eskalen, A. 2009. First report of Neofusicoccum australe, $N$. luteum, and N. parvum associated with avocado branch canker in California. Plant Dis. 93:967.

Mehl, J., Wingfield, M. J., Roux, J., and Slippers, B. 2017a. Invasive everywhere? Phylogeographic analysis of the globally distributed tree pathogen Lasiodiplodia theobromae. Forests 8:145.

Mehl, J. W., Slippers, B., Roux, J., and Wingfield, M. J. 2017b. Overlap of latent pathogens in the Botryosphaeriaceae on a native and agricultural host. Fungal Biol. 121:405-419.

Menge, J., and Ploetz, R. C. 2003. Diseases of avocado. Pages 35-71 in: Diseases of Tropical Fruit Crops. R. C. Ploetz, ed. CABI Publishing, Cambridge, U.K.

Molina-Gayosso, E., Silva-Rojas, H. V., García-Morales, S., and Avila-Quezada, G. 2012. First report of black spots on avocado fruit caused by Neofusicoccum parvum in Mexico. Plant Dis. 96:287.

Montealegre, J. R., Ramírez, M., Riquelme, D., Armengol, J., León, M., and Pérez, L. M. 2016. First report of Neofusicoccum australe in Chile causing avocado stem-end rot. Plant Dis. 100:2532.

Morales, A., Latorre, B. A., Piontelli, E., and Besoain, X. 2012. Botryosphaeriaceae species affecting table grape vineyards in Chile and cultivar susceptibility. Cienc. Inv. Agr. 39:445-458
Ni, H. F., Liou, R. F., Hung, T. H., Chen, R. S., and Yang, H. R. 2009. First report of a fruit rot disease of avocado caused by Neofusicoccum mangiferae. Plant Dis. 93:760.

ODEPA-CIREN. 2017. Catastro Frutícola, Región de Valparaíso. Principales Resultados. Santiago, Chile.

Pérez, C. A., Wingfield, M. J., Slippers, B., Altier, N. A., and Blanchette, R. A. 2010. Endophytic and canker-associated Botryosphaeriaceae occurring on non-native Eucalyptus and native Myrtaceae trees in Uruguay. Fungal Divers. 41:53-69.

Phillips, A., Alves, A., Correia, A., and Luque, J. 2005. Two new species of Botryosphaeria with brown, 1-septate ascospores and Dothiorella anamorphs. Mycologia 97:513-529.

Phillips, A. J. L., and Alves, A. 2009. Taxonomy, phylogeny, and epitypification of Melanops tulasnei, the type species of Melanops. Fungal Divers. 38: 155-166.

Phillips, A. J. L., Alves, A., Abdollahzadeh, J., Slippers, B., Wingfield, M. J., Groenewald, J. Z., and Crous, P. W. 2013. The Botryosphaeriaceae: Genera and species known from culture. Stud. Mycol. 76:51-167.

Prusky, D., and Keen, N. T. 1993. Involvement of preformed antifungal compounds in the resistance of subtropical fruits to fungal decay. Plant Dis. 77:114-119.

Schaffer, B. N., Wolstenholme, B. N., and Whiley, A. W. 2013. Introduction. Pages 1-9 in: The Avocado: Botany, Production and Uses. B. Schaffer, B. N. Wolstenholme, and A. W. Whiley, eds. CABI International Press, Wallingford, U.K.

Slippers, B., Crous, P. W., Denman, S., Coutinho, T. A., Wingfield, B. D., and Wingfield, M. J. 2004a. Combined multiple gene genealogies and phenotypic characters differentiate several species previously identified as Botryosphaeria dothidea. Mycologia 96:83-101.

Slippers, B., Crous, P. W., Jami, F., Groenewald, J. Z., and Wingfield, M. J. 2017. Diversity in the Botryosphaeriales: Looking back, looking forward. Fungal Biol. 121:307-321

Slippers, B., Fourie, G., Crous, P. W., Coutinho, T. A., Wingfield, B. D., and Wingfield, M. J. 2004b. Multiple gene sequences delimit Botryosphaeria australis sp. nov. from B. lutea. Mycologia 96:1030-1041.

Slippers, B., and Wingfield, M. J. 2007. Botryosphaeriaceae as endophytes and latent pathogens of woody plants: Diversity, ecology and impact. Fungal Biol. Rev. 21:90-106.

Swofford, D. L. 2002. PAUP*: Phylogenetic Analysis Using Parsimony (*and Other Methods), version 4.0b10. Sinauer Associates, Sunderland, MA.

Tamura, K., Stecher, G., Peterson, D., Filipski, A., and Kumar, S. 2013. MEGA6: Molecular evolutionary genetics analysis version 6.0. Mol. Biol. Evol. 30: 2725-2729.

Twizeyimana, M., Förster, H., McDonald, V., Wang, D. H., Adaskaveg, J. E., and Eskalen, A. 2013. Identification and pathogenicity of fungal pathogens associated with stem-end rot of avocado in California. Plant Dis. 97: 1580-1584.

Úrbez-Torres, J. R., Battany, M., Bettiga, L. J., Gispert, C., McGourty, G., Roncoroni, J., Smith, R. J., Verdegaal, P., and Gubler, W. D. 2010. Botryosphaeriaceae species spore-trapping studies in California vineyards. Plant Dis. 94:717-724.

Valencia, A. L., Torres, R., and Latorre, B. A. 2011. First report of Pestalotiopsis clavispora and Pestalotiopsis spp. causing postharvest stem end rot of avocado in Chile. Plant Dis. 95:492.

Valencia, D., Torres, C., Camps, R., López, E., Celis-Diez, J. L., and Besoain, X. 2015. Dissemination of Botryosphaeriaceae conidia in vineyards in the semiarid Mediterranean climate of the Valparaíso Region of Chile. Phytopathol. Mediterr. 54:394-402

White, A., Woolf, A. B., Hofman, P. J., and Arpaia, M. L. 2005. The International Avocado Quality Manual. Horticulture and Food Research Institute, Auckland, New Zealand.

White, T. J., Bruns, T., Lee, S., and Taylor, J. 1990. Amplified and direct sequencing of fungal ribosomal RNA genes for phylogenies. Pages 315-322 in: PCR Protocols: A Guide to Methods and Applications. M. A Innis, D. H. Gelfand, J. J. Sninsky, and T. J. White, eds. Academic Press, San Diego, CA.

Yahia, E. M., and Woolf, A. B. 2011. Avocado (Persea americana Mill.). Pages 125-186 in: Postharvest Biology and Technology of Tropical and Subtropical Fruits. E. M. Yahia, ed. Woodhead Publishing, Cambridge, U.K.

Zea-Bonilla, T., Gonzalez-Sanchez, M. A., Martin-Sanchez, P. M., and PerezJimenez, R. M. 2007. Avocado dieback caused by Neofusicoccum parvum in the Andalucía Region, Spain. Plant Dis. 91:1052. 